\title{
The history of settlement and agrarian land use in a boreal forest in Värmland, Sweden, new evidence from pollen analysis
}

\author{
Sigrún Dögg Eddudóttir ${ }^{1}\left[\right.$ (D) Eva Svensson ${ }^{2} \cdot$ Stefan Nilsson $^{3} \cdot$ Anneli Ekblom $^{1} \cdot$ Karl-Johan Lindholm $^{1}$. \\ Annie Johansson ${ }^{4}$
}

Received: 10 November 2020 / Accepted: 25 February 2021 / Published online: 17 March 2021

(c) The Author(s) 2021

\begin{abstract}
Shielings are the historically known form of transhumance in Scandinavia, where livestock were moved from the farmstead to sites in the outlands for summer grazing. Pollen analysis has provided a valuable insight into the history of shielings. This paper presents a vegetation reconstruction and archaeological survey from the shieling Kårebolssätern in northern Värmland, western Sweden, a renovated shieling that is still operating today. The first evidence of human activities in the area near Kårebolssätern are Hordeum- and Cannabis-type pollen grains occurring from ca. 100 BC. Further signs of human impact are charcoal and sporadic occurrences of apophyte pollen from ca. AD 250 and pollen indicating opening of the canopy ca. AD 570, probably a result of modification of the forest for grazing. A decrease in land use is seen between AD 1000 and 1250 , possibly in response to a shift in emphasis towards large scale commodity production in the outlands. Emphasis on bloomery iron production and pitfall hunting may have caused a shift from agrarian shieling activity. The clearest changes in the pollen assemblage indicating grazing and cultivation occur from the mid-thirteenth century, coinciding with wetter climate at the beginning of the Little Ice Age. The earliest occurrences of anthropochores in the record predate those of other shieling sites in Sweden. The pollen analysis reveals evidence of land use that predates the results of the archaeological survey. The study highlights how pollen analysis can reveal vegetation changes where early archaeological remains are obscure.
\end{abstract}

Keywords Sweden $\cdot$ Norway $\cdot$ Pollen $\cdot$ Archaeology $\cdot$ Land use $\cdot$ Boreal forest $\cdot$ Settlement $\cdot$ Agriculture

\section{Introduction}

Transhumance, the movement of livestock to grazing areas over longer or shorter distances, has occurred in many parts of the world since the early days of agriculture and

Communicated by M.-J. Gaillard.

Sigrún Dögg Eddudóttir

sigrun.dogg.eddudottir@arkeologi.uu.se

1 Department of Archaeology and Ancient History, Uppsala University, Engelska Parken, Thunbergsvägen $3 \mathrm{H}$, 75238 Uppsala, Sweden

2 Centre for Research On Sustainable Societal Transformation \&, Department of Political, Historical, Religious and Cultural Studies, Karlstad University, 65188 Karlstad, Sweden

3 Geographica Antikva, Stationsvägen 14, 68697 Lysvik, Sweden

4 Länsstyrelsen Värmland (County Administrative Board), Våxnäsgatan 5, 65186 Karlstad, Sweden continues today. Historically, transhumance operated as a means to expand agrarian opportunities, especially grazing areas, where they were naturally scarce. This type of transhumance is steadily decreasing and has been abandoned in most places. The shieling system, the historically known form of transhumance in Scandinavia is governed by local rules for outland use within communities (Costello and Svensson 2018). Shielings (fäbod or säter in Swedish, seter in Norwegian) are sites for seasonal use located in outlands, made up of meadows and buildings to house people and livestock. A range of activities beyond grazing may have been part of daily life at the shielings such as milking, hay making and dairy production. Livestock, often goats, cattle and sheep, were moved to the shieling from the farm for grazing during summer and grazed in the surrounding forests. The distance between shielings and the home farm or hamlet varied (often about $10 \mathrm{~km}$ ) and shielings were often located at higher altitudes than farms (Emanuelsson et al. 2003; Larsson 2009). The emergence of shielings in Scandinavia is debated. Norwegian archaeologist Bjørn Hougen suggested 
that transhumance and shielings in Scandinavia may have had an early beginning and preceded the establishment of permanent farms in the Norwegian inland river valleys in the Roman Iron Age (ca. AD 1-400) (Hougen 1947). In contrast, Norwegian and Swedish historians proposed that shielings emerged as a part of increased cattle breeding following the late medieval agrarian crisis (14th and 15 th centuries $\mathrm{AD}$ ), or in early modern times when agriculture had recovered from the same crisis (Sandnes 1989, 1991; Larsson 2009). However, fully developed shielings from the Viking age (ca. AD 800 to 1050) have been found in Iceland (Sveinbjarnardóttir 1991; Lucas 2008), the Faroe Islands (Mahler 2007) and Greenland (Ledger et al. 2013), suggesting the existence of a fully developed shieling system at the onset of Scandinavian colonisation of the North Atlantic.

Distinguishing between farm and shieling can be difficult based on archaeology alone and sometimes this can apply to palaeobotanical material as well. Traditionally, a shieling was used for haymaking, grazing and dairy production (Larsson 2009), whereas a farm was the centre of a more complex economy which also engaged in cereal cultivation. However, investigations of shielings often uncover evidence of cereal cultivation (e.g. clearance cairns, fossil fields and cereal pollen) (Olsson 1998; Svensson 1998; Emanuelsson et al. 2003). It is likely that land-use at shielings could be expanded in relation to the needs of the farms, when there were many children in the home or due to changing market conditions. Land use at shielings was flexible and there are also some indications that shielings (or parts thereof) were used as farms on a temporary or permanent basis, and deserted farms could be transformed into shielings (Svensson 1998). In Sweden, shielings were part of the general expansion of cattle breeding in the late middle ages and early modern times, probably to sell cattle to the Swedish Mining District (Svensson 1998; Emanuelsson 2001; Emanuelsson et al. 2003; Larsson 2009).

Low archaeological visibility and difficulties of interpretation long hampered research of shielings in Sweden. The earliest investigations, involving surveying and detailed mapping, showed that shieling sites were spread over large areas and included several dispersed house foundations of apparently indeterminable age. It is difficult to determine the oldest feature for excavation or to find alternative means of dating. As archaeological evidence does not allow the identification of the earliest structures for excavations, pollen analysis can be utilised to shed light on the establishment of shielings and development of land use associated with them. Pollen analysis has for example revealed the use of sites in Norway and Sweden for occasional grazing in an early phase of recurrent use of outland sites from the late Bronze Age-Early Iron Age (e.g. Magnus 1986; Kvamme 1988).

This paper will present the results from a pollen based vegetation reconstruction and detailed archaeological survey from the shieling Kårebolssätern in northern Värmland, western Sweden. The shieling has been renovated and is still operating today. The aim of the paper is to examine the land use history of Kårebolssätern. We seek to answer the questions: (1) When are the first indicators of human impact and land use recorded in the pollen record? (2) How did land use develop over time at Kårebolssätern? (3) Are the results of the pollen analysis consistent with the archaeological record? (4) How does the development of land use at Kårebolssätern compare to other sites in Scandinavia?

\section{Kårebolssätern shieling}

The shieling Kårebolssätern in northern Värmland, Torsby Municipality, is located at the southeast end of the lake of Kårebolssjön, at an elevation of 348 m a.s.l., (Fig. 1). The shieling is located ca. $9 \mathrm{kms}$ east of the mother hamlet Kårebol. The number of farmsteads in the Kårebol hamlet has varied over time. The map of Hundreds from ca. 1883-1895, when the settlement peaked, shows nine farmsteads. Kårebol is located within a narrow river valley on the west bank of the river Klarälven, while the shieling is situated upon a forested mountain plateau above the eastern flank of the valley (Fig. 2). The separation of hamlet and shieling on different sides of the river Klarälven is quite unusual in this region. The shieling is located on forested land owned by another hamlet, Elindebol situated on the eastern shore of the river Klarälven. Only the forest closest to the shieling belongs to Kårebol (Sundquist and Johansson 2014). This arrangement is possibly the result of an exchange of land between the two hamlets, presumed to have taken place in the 17th century. It is unclear if this exchange of land included Kårebolssätern or not. No shieling associated with Kårebol appears on the earliest map of the area from 1697, or on the first partition map for Kårebol from 1799. Kårebolssätern first appears on historical maps in 1815 , on the first partition map for

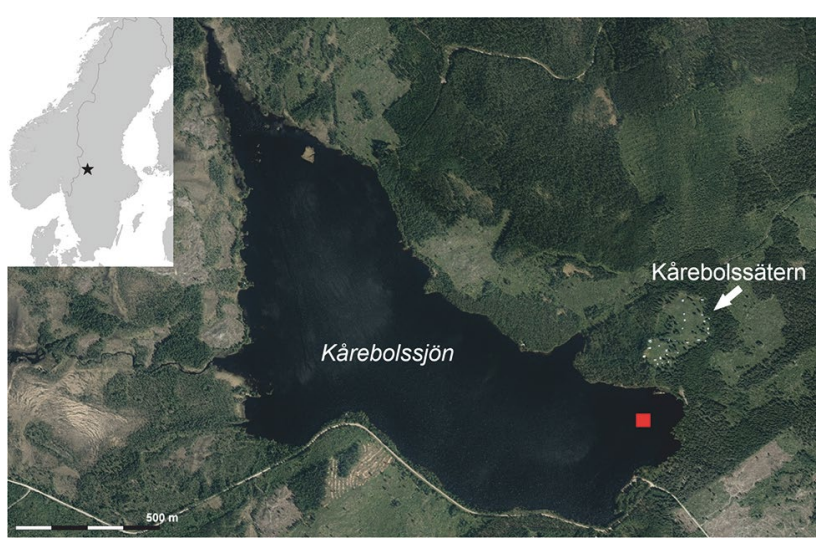

Fig. 1 Map showing the shieling Kårebolssätern and the coring site (red square). Source Lantmäteriet 


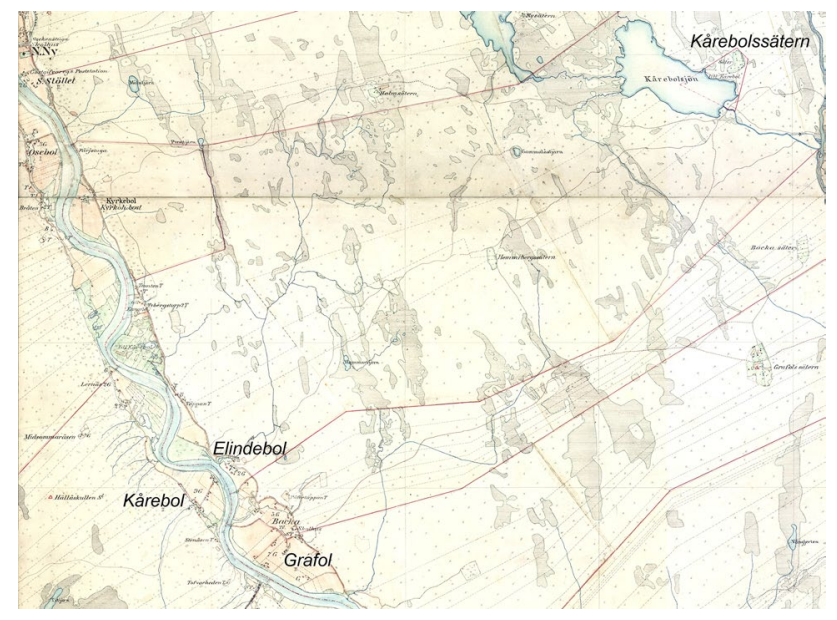

Fig. 2 Map of Hundreds from ca. 1880-1895 showing Kårebolssätern, Kårebol, Elindebol and Gravol (Grafol). Source: Häradsekonomiska kartan 1883-1895 (Lantmäteriet 2021)

Elindebol. After that Kårebolssätern appears in several historical maps covering Kårebol and Elindebol (Nilsson et al. 2018).

The age of the Kårebol hamlet is not known, nor that of the possible prior mother hamlet Elindebol. Both hamlets have the suffix -bol, dating back to medieval times and later. The prefix Kåre, a pre-Christian male name, could indicate that Kårebol could date back to pre-Christian times (before ca. AD 1000) whereas Elindebol would be younger. Both hamlets were probably secondary units to an older hamlet, possibly nearby Gravol. The suffix -vol is probably the same as -vold, commonly indicating old, rural settlements in Norway (Rosell 1981). None of the three hamlets Gravol, Elindebol or Kårebol are known in any written documents prior to the earliest tax ledger from 1503 (Björklund 2018).

Kårebolssätern is a uniquely well preserved, or rather, a well restored shieling (Fig. 3), consisting of about 30 buildings, mainly dwelling houses, cow houses and barns. The shieling was abandoned in 1973 but reclaimed in 1988 and is managed by a local cultural heritage society (Länsstyrelsen Värmland 2020). The pasture of the shieling is today surrounded by a forest of Norway spruce (Picea abies). Birch trees (Betula pubescens, B. pendula) form a boundary between the shieling meadow and the surrounding forest. Grazing and meadow management are still practiced and since its reopening in 1988 the shieling meadow has been mowed by scythe. Cows and horses graze the meadow during summer, although in the past livestock grazed in the surrounding forests and were prevented from entering the meadow inside the shieling fence (Fig. 3). A vegetation survey of the meadows made in 2012 revealed the presence of apophytes such as pyramidal bugle (Ajuga pyramidalis), greater butterfly-orchid (Platanthera chlorantha), heath speedwell (Veronica officinalis) and matgrass (Nardus stricta). The shieling is located within a forest owned by Elindebol, therefore only the forest closest to the shieling belongs to Karrebol and forest grazing has historically taken place in forest common with Elindebol hamlet (Sundquist and Johansson 2014).
Fig. 3 The shieling Kårebolssätern. a Central meadow area with haybarns, $\mathbf{b}$ a cow house, connected to the fence surrounding the shieling (the entrance for the livestock faced the forest, preventing the cattle from entering the meadows), c house foundation of pre-modern character. Photos: Eva Svensson

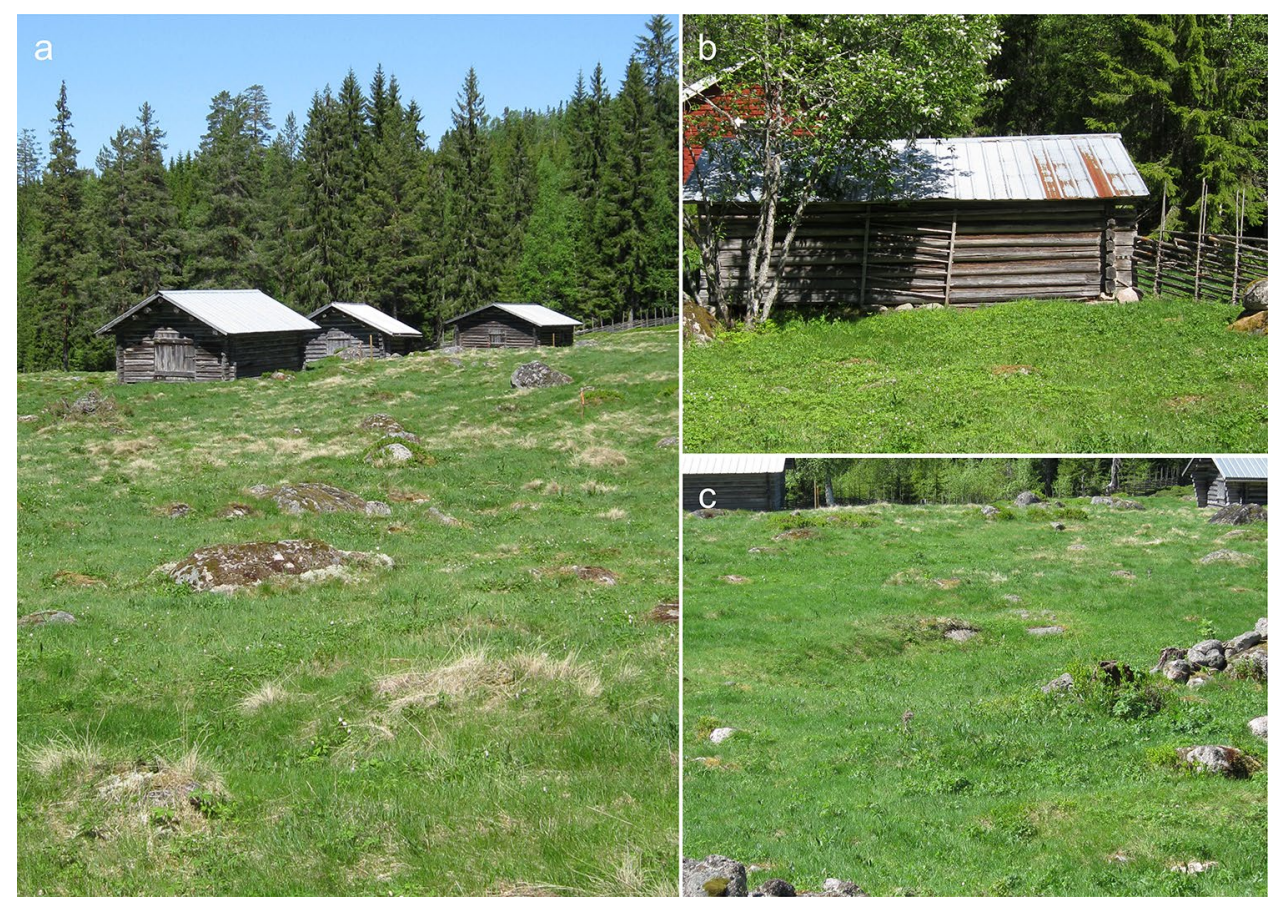




\section{Materials and methods}

\section{Coring}

Fieldwork to retrieve a sediment core for pollen analysis was carried out on 7th February 2019 in the southeast end of Kårebolssjön ( $60^{\circ} 24^{\prime} 7^{\prime \prime N}$, 1325'52"E, Fig. 1). A $100 \mathrm{~cm}$ long core was retrieved using a $7.5 \mathrm{~cm}$ diameter Russian peat corer. The water depth at the coring site was $317 \mathrm{~cm}$. The coring site is located at a distance of about $170 \mathrm{~m}$ from the south end of the shieling, with a difference in elevation of about $20 \mathrm{~m}$ between the lake surface and the shieling. No possible sites for coring were identified near the shieling or in the surrounding forest, and therefore the southeast end of the lake was selected as the location for the coring site. Kårebolssjön is large, with a surface area of about $1 \mathrm{~km}^{2}$ and it therefore likely has a large source area for pollen (Sugita 1994, 2007). However, given the location of the coring site at the end of the lake, close to the shieling, a pollen signal from the shieling site, once established, should be discernible in the data.

\section{Chronology}

Six bulk sediment samples were sent for radiocarbon dating at the Tandem Laboratory, Uppsala University (Table 1). Bulk sediment samples were used due to absence of terrestrial macrofossils for dating in the sediment. The radiocarbon dates were calibrated using the IntCal20 calibration curve (Reimer et al. 2020) and a smooth spline age-depth model for the core (Fig. 4) was constructed, based on the radiocarbon dates, using the $\mathrm{R}$ package clam (Blaauw 2010).

\section{Sampling and analysis}

The core was subsampled every $2 \mathrm{~cm}$ for pollen analysis. Pollen samples were prepared using standard methods with $10 \% \mathrm{HCl}, 10 \% \mathrm{NaOH}$, acetolysis (Moore et al. 1991) and density separation (Björck et al. 1978; Nakagawa et al. 1998). A total of 31 samples were counted spanning a depth

Table 1 Results of radiocarbon dating of samples from the Kårebolssjön sediments

\begin{tabular}{llccc}
\hline Lab code & Sample & $\delta^{13} \mathrm{C}(\% \circ)$ & ${ }^{14} \mathrm{C}$ age $\mathrm{BP}$ & Calibrated age \\
\hline Ua-62418 & KAR330 & $-28,5$ & $700 \pm 27$ & AD $1324 \pm 60$ \\
Ua-64909 & KAR341 & -29.0 & $1,011 \pm 29$ & AD $1062 \pm 86$ \\
Ua-64910 & KAR343 & -28.8 & $1,091 \pm 29$ & AD 953 \pm 60 \\
Ua-64911 & KAR359 & -29.3 & $2,172 \pm 30$ & $239 \pm 121$ BC \\
Ua-64912 & KAR373 & -29.3 & $2,477 \pm 31$ & $602 \pm 170$ BC \\
Ua-62419 & KAR390 & $-28,9$ & $2,985 \pm 29$ & $1203 \pm 87$ BC \\
\hline
\end{tabular}

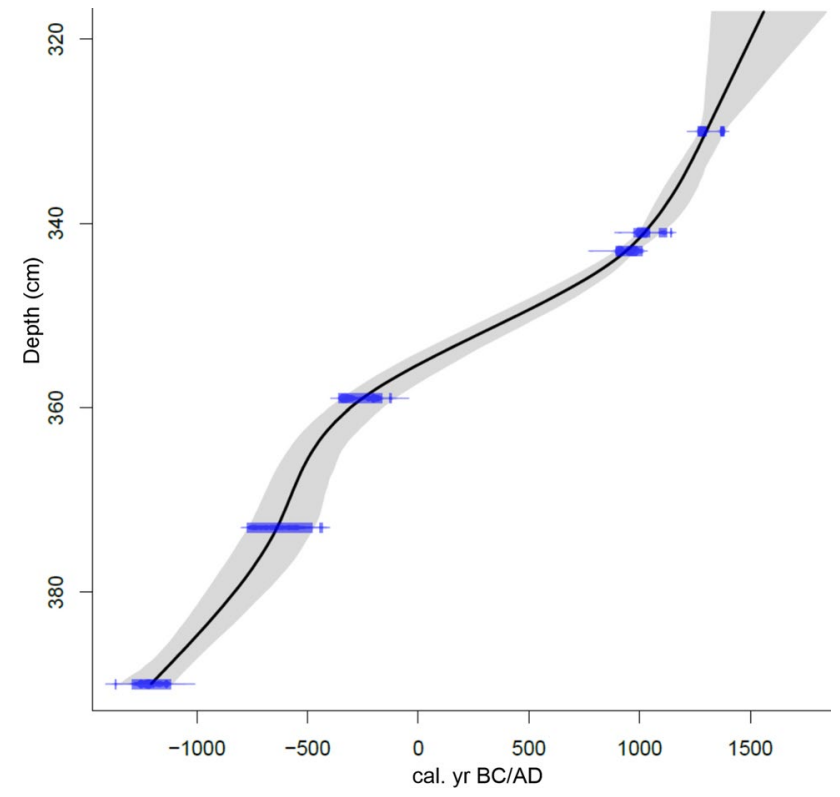

Fig. 4 Age-depth model for the Kårebolssjön core

between 318 and $378 \mathrm{~cm}$ (measured from the water surface). A minimum of 500 terrestrial pollen grains were counted for each sample. Coprophilous fungal spores, pteridophyte spores, and microscopic charcoal were also recorded. Identification of pollen grains and spores was based on Moore et al. (1991) and pollen and spore taxonomy followed Bennett (2007). Identification of coprophilous fungal spores relied on Cugny et al. (2010) and van Geel et al. (2007). Pollen, spore and charcoal percentages were calculated based on the total sum of terrestrial pollen grains. Samples were divided into pollen assemblage zones (PAZs) using CONISS analysis in the software Tilia (Grimm 2016). Samples for measurements of organic matter $(\mathrm{OM})$ were taken every $1 \mathrm{~cm}$ and measured by loss on ignition, by combusting the sample at $550^{\circ} \mathrm{C}$ for $4 \mathrm{~h}$. Dry bulk density (DBD) was measured where enough material was available, by dividing the dry weight of $1.2 \mathrm{~cm}^{-3}$ of sediment by the original volume (Aaby and Berglund 1986).

\section{Map analysis and archaeological field-survey}

Detailed mapping was conducted at Kårebolssätern in the early summer of 2018 guided by historical maps (Nilsson et al. 2018). The mapping was carried out by walking the area inside the fences of the shieling and a few metres outside the fences, looking for visible traces of buildings, other constructions and traces of land use. The detailed mapping also included checking some detected remains for cultural layers with a single gouge auger. Parts of the shieling were covered successively, starting in the south-western part, moving on to the southeast and finally the northern part. 
The locations of buildings and other features on the historical maps were transferred to ArcGIS prior to fieldwork and used during the detailed mapping for comparison with structures found in the field. All structures and remains were mapped in ArcGIS.

\section{Results}

\section{Chronology}

The age-depth model for the core was constructed using dates from bulk sediments in the absence of terrestrial plant macrofossils in the sediments (e.g. Ascough et al. 2011; Philippsen 2013). Dates obtained from bulk sediments can be considered to be reliable as the bedrock in the research area does not include calcareous rock that can cause a freshwater reservoir effect (Bergman et al. 2012). The reliability of the results of the radiocarbon dating can be confirmed by using the Picea pollen record as age control for the core. A pollen study from Stor-Flen about $63 \mathrm{~km}$ east of Kårebolssätern gives the date of $410 \mathrm{BC}-\mathrm{AD} 30$ for Picea colonisation (Segerström 1997) and other studies suggest similar dates (Påhlsson 1988; Eriksson 1991; Giesecke and Bennett 2004). With the suggested age-depth model (Fig. 4), Picea pollen begins to increase in the Kårebolssjön core ca. $240 \pm 120 \mathrm{BC}$, which is in good accordance with the previous studies. This is therefore an indication that the radiocarbon dates used in the age-depth model provide a good approximate age of the changes observed in the data.

\section{Pollen analysis}

\section{PAZ 1 (358-378 cm; 600-200 вC)}

The earliest pollen assemblage is dominated by tree pollen; birch (Betula) 47-70\%, Pinus 9-38\%, and Alnus 6-14\%. Pollen of broadleaved trees are recorded, such as Quercus $(\leq 2.3 \%)$, Ulmus $(\leq 1 \%)$ and Tilia $(\leq 1.5 \%)$. Picea pollen is present in very low percentages $(<1 \%)$ until ca. $550 \mathrm{BC}$ $(368 \mathrm{~cm})$, after which it increases to $\sim 4 \%$. Fern spores range between 1-2\% (Fig. 5). Microscopic charcoal is 3-9\%.

\section{PAZ 2 (342-358 cm; 200 BC-AD 1000)}

Picea pollen increases to $>10 \%$ in all but one level, while Betula pollen ranges between $\sim 27-45 \%$. Meanwhile, the pollen of broadleaved trees decreases, Quercus $(\leq 1.1 \%)$, Ulmus (0-0.6\%) and Tilia $(\leq 0.4 \%)$ ca. 100 вс $(356 \mathrm{~cm})$, and fern spores (Pteropsida) decrease to $<1 \%$ between ca. 100 BC and AD 200 (356-352 cm). Charcoal fragments are recorded increasingly within this $\mathrm{PAZ}$ reaching $\geq 10 \%$ after ca. AD 250 $(352 \mathrm{~cm})$. Pollen grains of cereals, mainly Hordeum-type, as well as Cannabis-type pollen appear within this PAZ, although mostly as single pollen grains. Pollen suggesting agrarian land-use e.g. Asteraceae, Chenopodiaceae, and Plantago media/major, appear within this PAZ. Picea pollen decreases upwards within this PAZ (Fig. 5).

\section{PAZ 3 (332-342 cm; AD 1000-1250)}

There is a relative increase in Pinus pollen $(\sim 53-60 \%)$ and decrease in birch pollen $(\sim 19-25 \%)$ between ca. AD 1000 and 1250 (342-332 cm). Apophyte pollen of Chenopodiaceae, Plantago media/major and Rumex acetosa/acetocella are recorded while Melampyrum appears towards the top of the PAZ. Charcoal fragments are $7-18 \%$ within this PAZ (Fig. 5).

\section{PAZ 4 (332-318 cm; after AD 1250)}

There is a decrease in Pinus pollen at ca. AD $1250(332 \mathrm{~cm})$ to $<39 \%$, and a relative increase in birch $\sim 31-44 \%$. At the same time there is an increase in Juniperus-type $(>1 \%)$ and Rumex acetosa/acetocella pollen. Cereal pollen of Avenatype, Secale cereale and Hordeum-type, and pollen of Cannabis-type is recorded more frequently. Charcoal increases to $>18 \%$ within this PAZ. Occasional spores of coprophilous fungi of Sordaria-type and one spore of Apiosordaria vernaculosa are recorded, there is also an increase in Coniochaeta B spores. Poaceae (1-5\%) and Cyperaceae (0.5-2\%) pollen reach their highest values in the record. Pollen of apophytes Chenopodiaceae, Melampyrum, Plantago sp. and Rumex acetosa/acetocella is recorded in this PAZ. Sphagnum spores are most abundant in the record within this PAZ, 6-17\% (Fig. 5).

\section{Sedimentary properties}

The sediment consisted of gyttja containing between 32 and $58 \%$ organic matter (OM), having a dry bulk density (DBD) of 0.2 to $0.4 \mathrm{~g} \mathrm{~cm}^{-3}$ (Fig. 5). The DBD is relatively high in the lowest part of the core, with values $\geq 0.3 \mathrm{~g} \mathrm{~cm}^{-3}$ before ca. $700 \mathrm{BC}(375 \mathrm{~cm})$. The OM is relatively low during the same period, $\sim 32-36 \%$ in the lowest samples, increasing to $>39 \%$ ca. $700 \mathrm{BC}(375 \mathrm{~cm})$ as DBD decreases to $<0.25 \mathrm{~g} \mathrm{~cm}^{-3}$. DBD increases, peaking at $\sim 0.36-0.41 \mathrm{~g} \mathrm{~cm}^{-3}$, between ca. 250 BC-AD 450 $(359-350 \mathrm{~cm})$. The OM decreases to $<37 \%$ during the same period. The DBD decreases to $\leq 0.27 \mathrm{~g} \mathrm{~cm}^{-3}$ ca. AD 950 $(343 \mathrm{~cm})$. Both OM and DBD increase ca. AD $1250(332 \mathrm{~cm})$. $\mathrm{OM}$ increases to the highest values in the core, $42-58 \%$, after ca. AD 1400 (Fig. 5). 


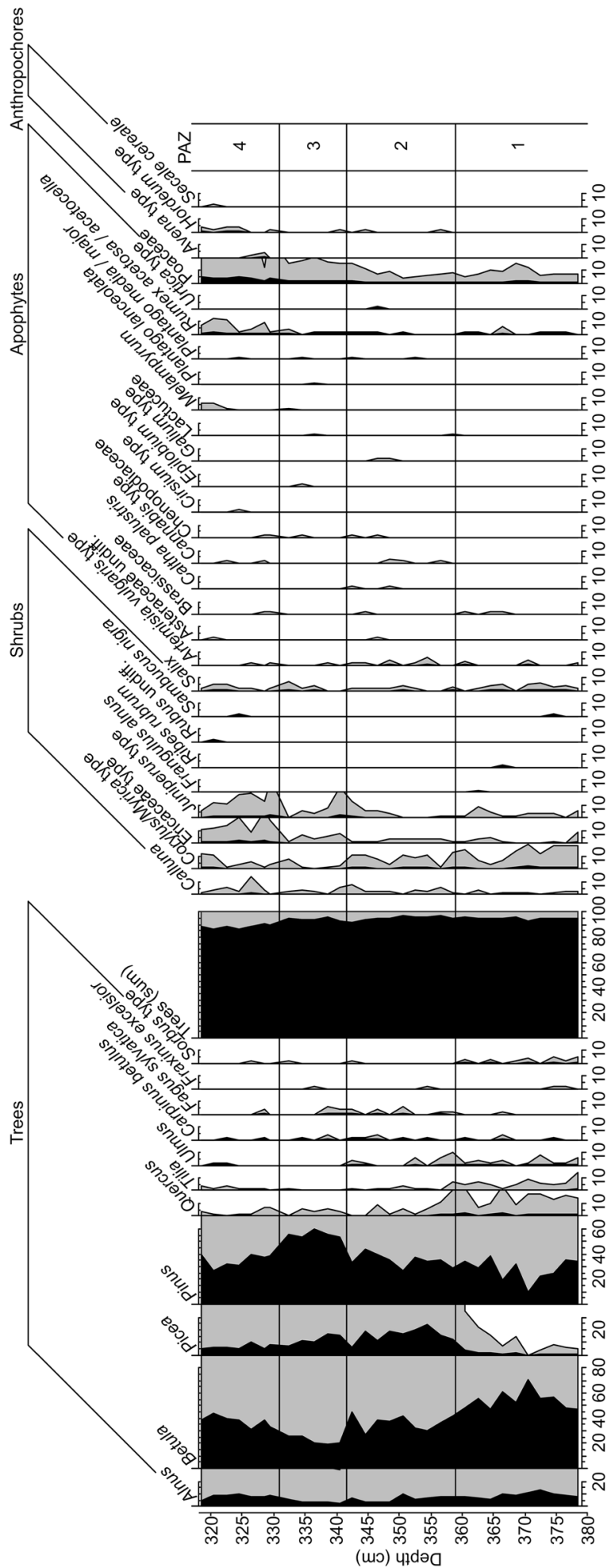

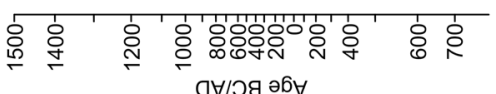

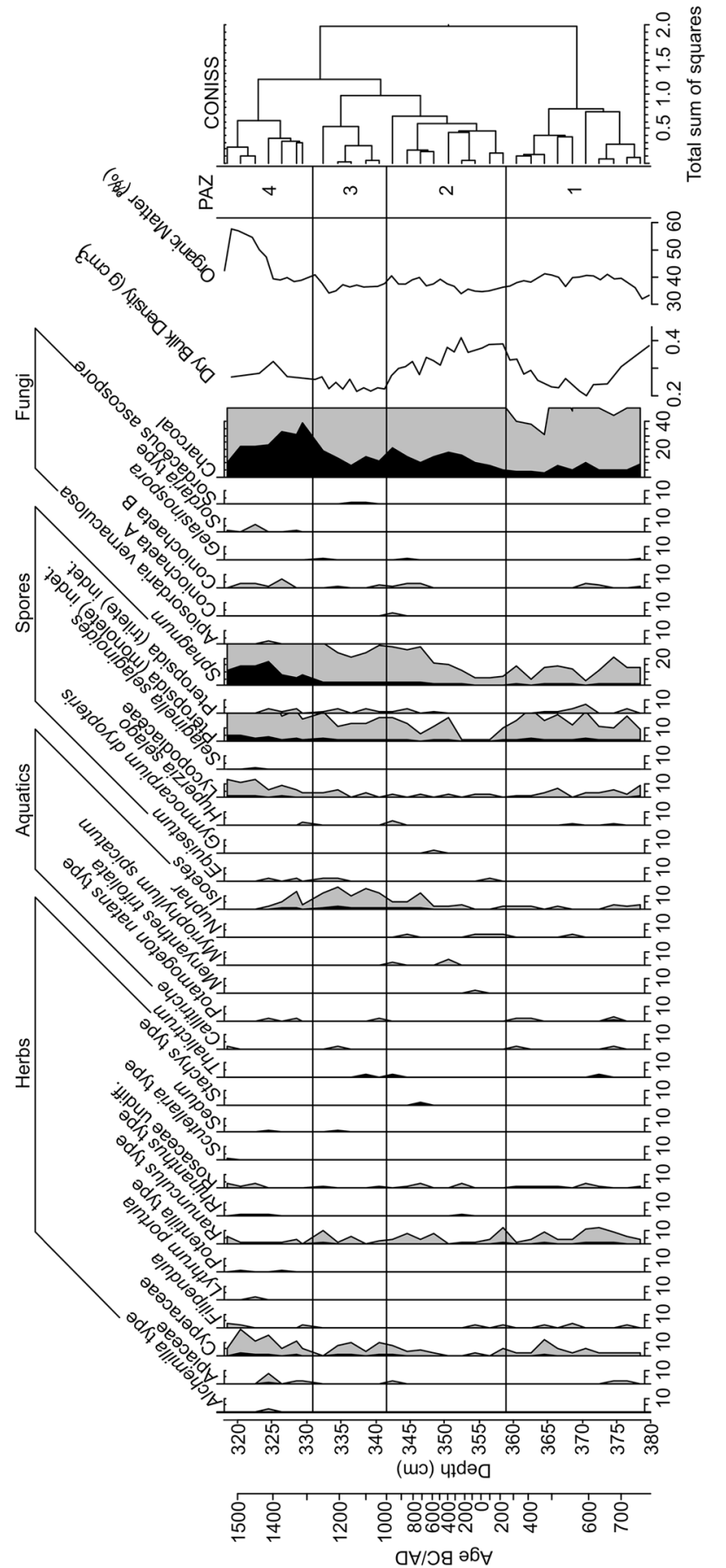

Fig. 5 Percentage pollen diagram, dry bulk density $\left(\mathrm{g} \mathrm{cm}^{-3}\right)$, organic matter (\%) and CONISS from the Kårebolssjön core. Gray curves exaggerated $\times 10$ 


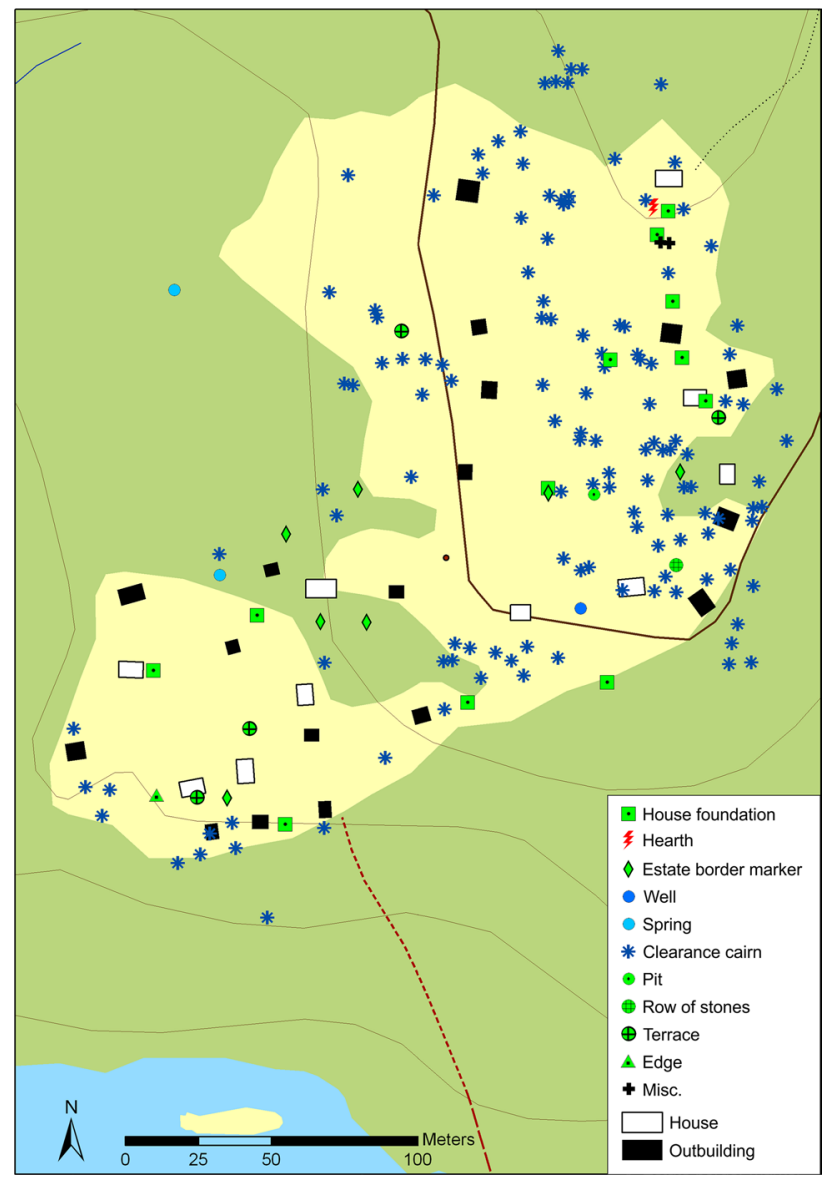

Fig. 6 Kårebolssätern. Structures recorded through detailed mapping and buildings standing today. "Edge" refers to "lynchet-like" features not clearly connected to fields. "Misc." refers to features connected to present day use of the shieling, i.e. buildings such as summer houses. Map: Stefan Nilsson

\section{Archaeological survey}

The archaeological features mapped at Kårebolssätern are commonly found at other shielings in the area and indicate cattle grazing, dairy production, haymaking and some cereal cultivation. Forty-five structures were mapped and described during fieldwork (Fig. 6). Several minor clearance cairns were mapped, but not described individually. The recorded structures included 12 house foundations, two wells, three areas with cultural layers, two fields and some features indicating additional fields, seven border stones marking the internal divisions of the shieling, the remains of a fireplace and c. ten larger clearance cairns. Four of the recorded house foundations at Kårebolssätern had remains of shallow cellar pits which may suggest pre-modern use. The house foundations did not match any buildings on historical maps, and are therefore considered to predate the oldest map, from 1815 . These buildings and many small clearance cairns without smaller stones, presumably of pre-modern origin, were concentrated in the south and southeast part of the shieling. The results of the archaeological survey suggest that Kårebolssätern is a relatively young shieling, based on dating of similar remains at other sites. House foundations with shallow cellar pits, house foundations with very low, squarish hearths and smaller clearance cairns without very small stones, such as those found at Kårebolssätern, have been dated to the 12th-16th century at other shielings in western Sweden, such as Backasätern, Ingersbysätern and Gammelvallen, Ängersjö (Magnusson 1989; Johansson and Svensson 2002; Emanuelsson et al. 2003). Thus, the four house foundations with shallow cellar pits recorded at Kårebolssätern may be pre-modern. The concentration of these buildings in the south and southeast part of the shieling, along with small clearance cairns without smaller stones, may suggest that this is the oldest part of the shieling. The north and northeast parts may have been younger extensions of Kårebolssätern. This hypothesis is reinforced by the fact that one house foundation of pre-modern character (Fig. 3c) is located in what is now the central part of the shieling. Houses, apart from hay barns, were usually built along shieling fences in order to not take up land from the meadows (Fig. 3).

\section{Discussion}

\section{Natural forest $(600-100 \mathrm{BC})$}

The earliest part of the pollen assemblage represents mixed boreal forest characterized by Betula and Pinus, Alnus and pollen of broadleaved trees Quercus, Ulmus and Tilia (Fig. 5). The high proportion of tree pollen, a relatively low presence of shrub pollen of Corylus/Myrica, Salix, Juniperus, Ericaceae and Calluna, and herb pollen, as well as the occurrence of fern spores (Pteropsida monolete) (Fig. 5) suggest a relatively closed forest canopy (Hicks 1988; Segerström et al. 1994). There are no clear signs of human presence in the pollen record during this period. Picea pollen appears ca. 550 BC and increases above $10 \%$ ca. 240 $\mathrm{BC}$ in accordance with the colonisation of the region by spruce observed in other studies (Segerström et al. 1996; Segerström 1997; Emanuelsson et al. 2003). As Picea pollen increases there is a relative decrease in Pinus, Betula, Quercus and Tilia pollen as well as fern spores (Fig. 5). A similar change in the pollen assemblage is recorded at other sites in the region, reflecting a change in the forest composition as a response to the expansion of Picea abies (Giesecke 2005). The increase in dry bulk density and a slight decrease in organic matter (Fig. 5), may suggest a change in the material deposited into Kårebolssjön. The increase in Picea abies may have changed the litter composition, and subsequently, soil chemistry possibly leading to increased soil erosion (Giesecke 2005). 


\section{First indications of agriculture (100 BC-AD 1000)}

The first indications of cultivation in the Kårebolssjön core appear ca. $100 \mathrm{BC}$, when individual pollen grains of Hordeum- and Cannabis-type are recorded with pollen grains of both taxa occurring sporadically thereafter. According to the age-depth model for the core the sample with the first occurrence of Hordeum- and Cannabis-type pollen has an age range of $180 \mathrm{BC}$ to $\mathrm{AD} 90$. The occasional occurrences of these pollen types, the presence of charcoal and some pollen types indicative of agrarian land use suggest some degree of farming near the lake between ca. $100 \mathrm{BC}$ and AD 250 (Fig. 5). Extensive cultivation, used to complement other methods of sustenance, may not be easily discerned from palynological or archaeological evidence (Behre 1981). Separating pollen of wild grasses and cereals can be challenging (e.g. Vorren 1986; Hannon and Bradshaw 2000; Edwards et al. 2005). Hordeum-type pollen is problematic as the group includes several wild grasses, such as Elytrigia repens and Glyceria fluitans that are common in Sweden (Den virtuella floran 2017). Care should therefore be taken in interpreting the origins of individual pollen grains of Hordeum-type. Cannabis-type pollen includes both pollen of Cannabis and Humulus. Although there have been attempts to distinguish between the two species there is a large overlap in morphologies (Moore et al. 1991). It is not known whether Humulus lupulus (hop) is native to Sweden or may have been imported (Strese et al. 2012). Cannabis sativa (hemp) has many traditional uses, including use for ropes and textiles, food, oil and medicinal use. The combination of cereal and Cannabis-type pollen at Anundsjö (in central Sweden) dated to 2500-2000 BC, similar to that in the Kårebolssjön record, is interpreted as indicative of cultivation at the site (Huttunen and Tolonen 1972). It is therefore possible that the results from Kårebolssjön indicate crop cultivation in the vicinity of the lake during the last centuries BC. Due to the relatively large size of Kårebolssjön it is not possible to say for certain whether the few pollen grains of anthropochores and apophytes recorded during this period originate from the shieling site or elsewhere in the catchment.

An increase in charcoal abundance after ca. AD 250 to $\geq 10 \%$ may be an indication of human activities in the area near the lake. Fire may have been used to clear forest and for management of pastures (Behre 1981; Vorren 1986; Segerström et al. 1996). Pollen of plants suggesting arable land use (i.e. Asteraceae and Chenopodiaceae) is occasionally recorded after ca. AD 500. Juniperus-type, Poaceae and Cyperaceae pollen begin to increase after ca. AD 600 (Fig. 5), indicating an opening of the canopy, and may signify grazing as Juniperus communis and Poaceae pollen are considered strong indicators of grazing (Behre 1981). The early evidence of land use is consistent with other studies from the region. The first evidence of grazing and cultivation at sites in the forest above the Klarälven river valley about $20 \mathrm{~km}$ northwest of the Kårebolssjön coring site is seen ca. AD 200-600 (Emanuelsson et al. 2003). Pollen studies from clearance cairns at two sites in Norway located about 125 and $150 \mathrm{~km}$ east of Kårebolssätern reveal cultivation had begun there during the Early Iron Age (Overland and Hjelle 2013).

The pollen analysis demonstrates that land use has a long history in the area near Kårebolssätern. The evidence of early cultivation of Hordeum and Cannabis do suggest an early phase, however none of the recorded archaeological remains at the shieling can be dated to this period. Remains of fields recorded during the survey at Kårebolssätern did not resemble fields from the centuries around AD in other parts of Scandinavia, such as large areas with clearance cairns or shallow, small sunken fields, so called celtic fields (Welinder et al. 1998). House foundations assessed as being of pre-modern character during the survey have their counterparts at other shielings dated to medieval and early modern times (Magnusson 1989; Johansson and Svensson 2002; Emanuelsson et al. 2003). House foundations dated before AD 600 in the mountain areas of southern Norway were long houses with well-built foundations of stones, earth and turf (Stene 2015), and no parallels to these were discovered at Kårebolssätern. It is possible that some of the house foundations of pre-modern character at Kårebolssätern are considerably older than the dated corresponding structures, but it is more likely that the early remains of buildings have not been identified. There is thus a knowledge gap concerning how to archaeologically identify remains of pre-medieval buildings and fields in shieling environments (Svensson 1998; Emanuelsson et al. 2003).

\section{Reduction in agrarian activities (AD 1000-1250)}

The relative increase in Pinus and decrease in Betula and Corylus/Myrica-type pollen ca. AD 1000-1250 (Fig. 5), may represent closing of the canopy in response to decreased land use. Betula trees and shrubs of Myrica gale may have decreased in response to decreased light availability as the canopy closed (Atkinson 1992; Skene et al. 2000). Juniperus communis pollen also decreases between ca. AD 1100 and 1200 , suggesting less light availability. Sporadic occurrences of apophyte pollen including Chenopodiaceae and Plantago media/major, indicating cultivation, may however suggest continuation of agricultural practices. Only one Hordeumtype pollen grain was recorded during this period, and may indicate a decrease in cereal cultivation (Fig. 5). The timing of this vegetation phase coincides with the increased importance of production of goods such as smelted iron, and hunting as shown from other sites in the region (Svensson 1998; Emanuelsson et al. 2003). The chronology of pitfall hunting 
systems in Värmland shows an increased emphasis towards hunting, with the highest number of pitfalls in the region dating to this period (Hennius 2020). New production patterns may have shifted the focus away from agrarian activities, resulting in linked changes in the vegetation community. The changes in the pollen assemblage do not suggest that the area around the coring site was used for iron production, as previous studies suggest that early iron production in the Swedish outlands may be manifested by a relative increase in Betula and decrease in Picea in pollen records (Emanuelsson 2001; Karlsson et al. 2016).

\section{Establishment of a dominant grazing regime (after AD 1250)}

The clearest signs of land use are seen in the record after ca. AD 1250. Hordeum-type pollen grains are found in low numbers in most samples from this period. Occasional pollen grains of Avena-type and Secale cereale as well as Cannabis-type are recorded (Fig. 5), indicating that cultivation became an increasingly important part of agrarian activities. The numerous clearance cairns, although also a result of haymaking, and several cultivation terraces identified during the field-survey (Fig. 6) indicate that cultivation was practiced at Kårebolssätern. The highest occurrence of charcoal is recorded during this period (Fig. 5) and can indicate the use of fire, perhaps as a tool for pasture management (Behre 1981; Vorren 1986; Segerström et al. 1996). An increase in Juniperus-type and Rumex acetosa/acetocella pollen may serve as an indicator of grazing as unpalatable and tough plants can benefit from grazing and trampling by livestock (Behre 1981; Vorren 1986) but are vulnerable to heavy grazing pressure (Thomas et al. 2007). Furthermore, the increase in shrub pollen such as Calluna and other ericaceous species, Corylus/Myrica-type, as well as Betula pollen (Fig. 5) may suggest clearing of woodland and a more open canopy. The presence of livestock during this period is perhaps indicated by the occurrence of spores of coprophilous fungi of Sordaria-type (Fig. 5), although the fungi may also be related to wild herbivores such as elk and deer. Coniochaeta B-type spores also increase during this period; these taxa are most commonly found on fern fallows and in heathlands (Cugny et al. 2010).

There is a stronger correspondence between the results from the archaeological survey and the pollen analysis in medieval, early modern and modern times. Fields, meadows and house foundations correspond fairly well with the results of the pollen analysis, although there are a few remains of a medieval to early modern character such as the house foundations with shallow cellar pits, house foundations with very low, squarish hearths and smaller clearance cairns. However, some of the more recent house remains and standing houses may use previous locations of buildings, and fields may have been in continuous use. The increased use of the shieling in modern times can most likely be connected with the northern extension of Kårebolssätern, assessed as more recent during the survey.

\section{Development of land use at Kårebolssätern}

The early beginning of land use at Kårebolssätern may predate both Kårebol and Elindebol, at least judging by their place names tentatively dated to ca. AD 1000 . It is possible that the shieling was previously connected to the hamlet Gravol, which appears to be of an older date (Rosell 1981). Kårebolssätern and its surroundings may have started off as a site used for recurrent grazing, characterising the first phases of shieling in an 'innovation package' farm-shieling (Emanuelsson 2001). Shieling sites in western Norway and western Sweden show evidence of periodic grazing (and sometimes haymaking as well) prior to the establishment of the historically known shieling mode. In Norway this phase is dated to the Bronze Age/Early Iron Age (Magnus 1986; Kvamme 1988) and in western Sweden to the middle or second half of the first millennium, while historically shielings are dated to the Viking Age and the Medieval Period (Olsson 1998; Emanuelsson 2001; Emanuelsson et al. 2003). Both in Norway and Sweden these early phases of outland use appear at the same time as farms. It may have been the combination of farm and shieling (albeit initially in a more sporadic form) that made feasible the expansion of settlement into rough terrain, such as dense forests or mountainous areas with little arable land (Emanuelsson 2001). In these areas, grazing and haymaking was scarce and scattered over great distances, and more recurrently used sites in the outland were needed to make the system work. Such sites matured and were shaped into the historically known shieling. Based upon interpretation of pollen data, the sites investigated so far in nearby regions have given starting dates several centuries younger than Kårebolssätern, although sites in western Norway have produced older dates (Kvamme 1988; Olsson 1998; Emanuelsson 2001; Emanuelsson et al. 2003). Still, the early dates for the onset of farming and grazing around Kårebolssjön would indicate that agrarian land use was established earlier in the area than the farm-shieling - outland use system, which so far has been dated to the middle of the first millennium or some centuries earlier in northern Värmland (Emanuelsson et al. 2003).

Sites in the south Norwegian mountain areas may be most comparable with the earliest phase of agrarian activities at Kårebolssätern, both in age and type of land use. During the first five centuries AD historically known shielings in the mountain areas of southern Norway show evidence of permanent and seasonal settlements with cattle breeding and outland use (Stene 2015). Land use at 
these sites could be complex, sometimes including cereal cultivation, and systems of pitfalls for reindeer, showing the importance of hunting. A hypothesis could therefore be that the area around Kårebolssjön started as a pioneer resource colonisation site, and Kårebolssätern became a shieling when the system of farm-shieling-outland use was established a few centuries later; a development similar to the Norwegian sites (Stene 2015), and possibly Backadammen, located about $25 \mathrm{~km}$ northwest of Kårebolssätern (Emanuelsson et al. 2003). Kårebolssätern could thus have been something of a frontier site, seasonally or permanently used in the extraction of commodities in line with the hunt for furs of bear and lynx for trading with the elite living on the plains (Lindholm and Ljungkvist 2016; Zachrisson and Krzewinska 2019). Settlement and agrarian land use were most likely organised in relation to the local requirements for the extraction of commodities such as furs, especially during the resource colonisation phase. Patterns such as these can be seen as significant for "ecological globalisation" where valuable resources result in interdependencies between the communities that extract the resource, and distant centres of consumption (Barrett et al. 2020). The process can be described as 'resource colonisation' at the local landscape level, shaping landscapes by the exploitation of valued resources for crafts and trade (Lindholm et al. in press). Cultivation of Cannabis sativa may have been important in this economy, as ropes were needed for packing and transporting commodities such as furs and later smelted iron. A similar pattern is seen at Backadammen where the first evidence of arable land use appears in the late Roman Iron Age (ca. AD 200-400) and Migration period (ca. AD 400-550), later followed by increased land use and grazing, traces of pitfall hunting and iron smelting (Emanuelsson et al. 2003). The farm-shieling relationship appears to have been especially blurred in the earlier phases, when linked with commodity extraction. With the establishment of the farm-shieling-outland use system after ca. AD 600, Kårebolssätern was most likely integrated into this system as a shieling as the mother farm/hamlet was established in the Klarälven river valley in the first centuries AD. In this phase, Kårebolssätern was possibly connected to the hamlet Gravol, which is thought to have been the older settlement in the river valley. In response to a growing population, new settlement units such as Kårebol and Elindebol were created through partitioning. Shielings could have been included in the outlands allotted to the new units, and Kårebolssätern could thus have become part of Elindebol, or more unlikely Kårebol, due to the later exchange of land.

A more closed canopy accompanied by a decrease in cereal pollen grains and changes in sediment properties (Fig. 5) between ca. AD 1000-1250 suggest a shift in land use at Kårebolssätern. The change in the vegetation and environment at the site may indicate a decrease in agrarian activities at Kårebolsätern coinciding in time with large scale commodity production in the outlands such as iron smelting and pitfall hunting. Similar reduction in agrarian activities has been detected at other shielings in the area, e.g. the nearby shieling Backasätern. It is likely that during this period, the available work force concentrated on producing bloomery iron and hunting, and shieling activities became less of a priority (Svensson 1998; Emanuelsson et al. 2003).

The intensified grazing regime and change in land use reflected in the pollen record in the late 13th and 14th centuries is in line with the increased emphasis on cattle breeding in Scandinavia as well as the regional transformation of the economy towards a larger degree of self-sufficiency when production and trade in iron and hunting products declined (Svensson 1998; Larsson 2009). The renewed agrarian land use at Kårebolssätern took place during a period of changing climate characterised by wetter conditions (Cook et al. 2015), reflected in an increase in spores of Sphagnum mosses that thrive in waterlogged, moist environments, beginning in the early 14th century (Fig. 5). Tree ring and isotope studies from Sweden suggest a period of wet summers between ca. AD 1300 and 1450 (Young et al. 2012; Rosqvist et al. 2013). Avena (oat) pollen is found in two samples dating from the 14th century, no Hordeum-type pollen is found in the same samples. This perhaps suggests changes in cultivation in the outlands when summers became wetter. This phase of land use continued for the remainder of the record. There is however a large age uncertainty towards the top of the record ( \pm 250 years) with the best estimate of the age-depth model of AD 1550. Therefore, it is possible that there is a gap in the record for early modern and modern times when use of shielings increased. Though historical maps show an intensification in shieling activities, this is not reflected in the pollen record from Kårebolssjön. Later, shielings went successively out of use with modern, industrialised agriculture in the 20th century.

\section{Conclusions}

The earliest evidence of human impact in the area near Kårebolssätern is Hordeum- and Cannabis-type pollen grains occurring from ca. 100 BC. Other signs of possible human impact on the environment in the area are charcoal, indicating clearing of forest and possibly pasture management, and sporadic occurrences of apophytes from ca. AD 250. An opening of the canopy after AD 600, indicates modification of the forest for grazing. Kårebolssätern may have started off as a place occupied and exploited on a seasonal basis for hunting and grazing. Settlement and agrarian land use may have been organised in relation to the local requirements 
for the extraction of commodities such as furs, charcoal and iron, during a resource colonisation phase.

Closing of the canopy in response to decreased land use between ca. AD 1000 and 1250 may be a response to a shift in emphasis towards large scale commodity production in the outlands, pitfall hunting and bloomery iron production, and a shift from agrarian shieling activities. The clearest changes in the pollen assemblage indicating grazing and cultivation occur from the mid-13th century, coinciding with wetter climate.

The earliest occurrences of anthropochores in the record predate those of most other shieling sites in Sweden and may best compare to land use history in Norwegian mountain areas, and possibly at nearby Backadammen in Värmland. The evidence of land use in the pollen record predates the archaeological evidence. The study highlights how pollen analysis can reveal vegetation changes where early archaeological remains are obscure.

Acknowledgements The authors would like to thank Guðrún Gísladóttir and Egill Erlendsson at the Institute of Life and Environmental Sciences at the University of Iceland for kindly offering us the use of laboratories and equipment for pollen analysis. Scott John Riddell is thanked for proof-reading the manuscript and his helpful suggestions. We would like to thank two anonymous reviewers for their valuable suggestions of ways in which to improve the manuscript. The research on Kårebolssätern was funded by Carl-Göran Adelswärds stiftelse (CGAS). The investigation of Kårebolssätern is also included in the project Contesting Marginality: The Boreal Forest of Inland Scandinavia and the Worlds Outside, ad-1500 ad (UTMA) financed by the Swedish Research Council (Dnr 2017-01483).

Funding Open access funding provided by Uppsala University.

Open Access This article is licensed under a Creative Commons Attribution 4.0 International License, which permits use, sharing, adaptation, distribution and reproduction in any medium or format, as long as you give appropriate credit to the original author(s) and the source, provide a link to the Creative Commons licence, and indicate if changes were made. The images or other third party material in this article are included in the article's Creative Commons licence, unless indicated otherwise in a credit line to the material. If material is not included in the article's Creative Commons licence and your intended use is not permitted by statutory regulation or exceeds the permitted use, you will need to obtain permission directly from the copyright holder. To view a copy of this licence, visit http://creativecommons.org/licenses/by/4.0/.

\section{References}

Aaby B, Berglund BE (1986) Characterization of peat and lake deposits. In: Berglund BE (ed) Handbook of Holocene palaeoecology and palaeohydrology. Wiley, Chichester, pp 231-246

Ascough PL, Cook GT, Hastie H et al (2011) An Icelandic freshwater radiocarbon reservoir effect: implications for lacustrine 14C chronologies. Holocene 21:1,073-1,080

Atkinson MD (1992) Betula pendula Roth (B. verrucosa Ehrh.) and B. pubescens Ehrh. J Ecol 80:837-870
Barrett JH, Boessenkool S, Kneale CJ, O’Connell TC, Star B (2020) Ecological globalisation, serial depletion and the medieval trade of walrus rostra. Quat Sci Rev. https://doi.org/10.1016/j.quasc irev.2019.106122

Behre K-E (1981) The interpretation of anthropogenic indicators in pollen diagrams. Pollen Spores 23:225-245

Bennett KD (2007) Catalogue of pollen types. http://www.chrono. qub.ac.uk/pollen/pc-intro.html

Bergman S, Stephens M, Andersson J, Kathol B, Bergman T (2012) Sveriges Berggrund, skala 1:1 miljon (Bedrock Map of Sweden, scale 1:1 Million). Sveriges geologiska undersökning K 423

Björck S, Persson T, Kristersson I (1978) Comparison of two concentration methods for pollen in minerogenic sediments. Geol Fören Stockholm Förh 100:107-111

Björklund A (2018) Det medeltida Sverige 2 Värmland Andra delen. Riksarkivet, Stockholm

Blaauw M (2010) Methods and code for 'classical' age-modelling of radiocarbon sequences. Quat Geochronol 5:512-518. https://doi. org/10.1016/j.quageo.2010.01.002

Cook ER, Seager R, Kushnir Y et al (2015) Old World megadroughts and pluvials during the Common Era. Sci Adv. https://doi.org/10. 1126/sciadv. 1500561

Costello E, Svensson E (2018) Historical archaeologies of transhumance across Europe. Routledge, London

Cugny C, Mazier F, Galop D (2010) Modern and fossil non-pollen palynomorphs from the Basque mountains (western Pyrenees, France): the use of coprophilous fungi to reconstruct pastoral activity. Veget Hist Archaeobot 19:391-408

Den virtuella floran (2017) Naturhistoriska riksmuseet. http://linnaeus. $\mathrm{nrm} . \mathrm{se} /$ flora/welcome.html. Accessed 23 July 2020

Edwards KJ, Whittington G, Robinson M, Richter D (2005) Palaeoenvironments, the archaeological record and cereal pollen detection at Clickimin, Shetland, Scotland. J Archaeol Sci 32:1,741-1,756

Emanuelsson M (2001) Settlement and land-use history in the central Swedish forest region. Swedish University of Agricultural Sciences, Umeå

Emanuelsson M, Johansson A, Nilsson S, Pettersson S, Svensson E (2003) Settlement, shieling and landscape: the local history of a forest hamlet. Almkvist \& Wiksell International, Stockholm

Eriksson JA (1991) Kulturlandskapets historia speglad i två pollenanalyser. In: Björklund S, Pettersson TJ-E (eds) Lima och Transtrand Ur två socknars historia, vol 3. Malungs kommun, Malung, pp 9-26

Giesecke T (2005) Holocene dynamics of the southern boreal forest in Sweden. Holocene 15:858-872

Giesecke T, Bennett KD (2004) The Holocene spread of Picea abies (L.) Karst. in Fennoscandia and adjacent areas. J Biogeogr $31: 1,523-1,548$

Grimm EC (2016) TILIA 2.1.1. Illinois State Museum, Springfield

Hannon GE, Bradshaw RHW (2000) Impacts and timing of the first human settlement on vegetation of the Faroe Islands. Quat Res 54:404-413

Hennius A (2020) Towards a Refined Chronology of Prehistoric Pitfall Hunting in Sweden. Eur J Archaeol 23:530-546. https://doi.org/ 10.1017/eaa.2020.8

Hicks S (1988) The representation of different farming practices in pollen diagrams from northern Finland. In: Birks HH, Birks HJB, Kaland PE, Moe D (eds) The cultural landscape: past, present and future. Cambridge University Press, Cambridge, pp 189-207

Hougen B (1947) Fra seter til gård: studier i norsk bosetningshistorie. Norsk Arkeologisk Selskap, Oslo

Huttunen P, Tolonen M (1972) Pollen-analytical studies of prehistoric agriculture in northern Angermanland. Early Norrland 1:9-34

Johansson A, Svensson E (2002) Three shielings in Gunnarskog. In: Andersson S, Svensson E (eds) Skramle: the true story of a 
deserted medieval farmstead. Almkqist \& Wiksell International, Stockholm, pp 190-201

Karlsson J, Rydberg J, Segerström U, Nordström E-M, Thöle P, Biester H, Bindler R (2016) Tracing a bog-iron bloomery furnace in an adjacent lake-sediment record in Ängersjö, central Sweden, using pollen and geochemical signals. Veget Hist Archaeobot 25:569-581

Kvamme M (1988) Pollen analytical studies of mountain summerfarming in western Norway. In: Birks HH, Birks HJB, Kaland E, Moe D (eds) The cultural landscape: past, present and future. Cambridge University Press, Cambridge, pp 349-367

Lantmäteriet (2021) Häradsekonomiska kartan 1883-95. https://histo riskakartor.lantmateriet.se/arken/s/searchresult.html?archive $=$ GEOIN\&firstMatchToReturnLMS=1\&firstMatchToReturnREG= 1\&firstMatchToReturnRAK=1\&yMin=6692789\&xMin=40944 $8 \& \mathrm{yMax}=6700789 \& \mathrm{xMax}=417448$

Larsson J (2009) Fäbodväsendet 1550-1920: ett centralt element i Nordsveriges jordbrukssystem. Jamti Förlag, Östersund

Ledger PM, Edwards KJ, Schofield JE (2013) Shieling activity in the Norse eastern settlement: Palaeoenvironment of the 'Mountain farm', Vatnahverfi, Greenland. Holocene 23:810-822

Lindholm K-J, Ljungkvist J (2016) The bear in the grave: exploitation of top predator and herbivore resources in first millennium Sweden-first trends from a long-term research project. Eur J Archaeol 19:3-27

Lindholm K-J, Lindgren S, Hennius A, Lofsgarden K, Svensson E (in press) Contesting Marginality: The Boreal Forest of Inland Scandinavia and the Worlds Outside. The Medieval Globe, The Global North: Spaces, Connections, and Networks from the Iron Age to 1650

Lucas G (2008) Pálstóftir: A Viking age shieling in Iceland. Nor Archaeol Rev 41:85-100

Magnus BJ (1986) Iron Age exploitation of high mountain resources in Sogn. Nor Archaeol Rev 19:44-50

Magnusson G (1989) Medeltida fäbodlämningar i Ängersjö. In: Hemmendorff $\mathrm{O}$ (ed) Arkeologi i fjäll, skog och bygd. 2 Järnåldermedeltid. Jämtlands läns museum, Östersund, pp 167-174

Mahler DL (2007) Sæteren ved Argisbrekka. Økonomiske forandringer på Færøerne i vikingetid og tidlig middelalder. Annales Societatis Scientarium Færoensis 47. Faroe University Press, Tórshavn

Moore PD, Webb JA, Collison ME (1991) Pollen analysis. Blackwell Scientific Publications, Oxford

Nakagawa T, Brugiapaglia E, Digerfeldt G, Reille M, de Beaulieu J-L, Yasuda Y (1998) Dense-media separation as a more efficient pollen extraction method for use with organic sediment/deposit samples: comparison with the conventional method. Boreas 27:15-24. https://doi.org/10.1111/j.1502-3885.1998.tb00864.x

Nilsson S, Svensson E, Johansson A (2018) Kartering av Kårebolssätern 2018

Olsson M (1998) Pollenanalytiska undersökningar av sätermiljöer i Dalby och Gunnarskog socknar. Lund University, Lund, Värmland. LUDQUA uppdrag

Overland A, Hjelle KL (2013) Pollen analysis in the context of clearance cairns from boreal forests-a reflection of past cultivation and pastoral farming. J Archaeol Sci 40:1,029-1,041

Påhlsson I (1988) Kulturlandskapet. In: Mogren M, Svensson K (eds) Bondeplågarens borg: Om och kring undersökningen av fogdefästet Borganäs i Dalarna. Riksantikvarieämbetet, Stockholm, pp 27-29

Philippsen B (2013) The freshwater reservoir effect in radiocarbon dating. Heritage Science 1:24

Reimer PJ, Austin WEM, Bard E et al (2020) The IntCal20 Northern Hemisphere Radiocarbon Age Calibration Curve (0-55 cal kBP). Radiocarbon 62:725-757

Rosell E (1981) Nationen och hembygden: skriftserie. Press, Karlstad, Värmländsk medeltid i ortnamnsperspektiv
Rosqvist GC, Leng MJ, Goslar T et al (2013) Shifts in precipitation during the last millennium in northern Scandinavia from lacustrine isotope records. Quat Sci Rev 66:22-34

Sandnes J (1989) Ljåen og krøttermulen. Om opphav og alder til det norske seterbruket. Norsk Historisk Tidskrift 3/1989:351-358

Sandnes J (1991) Utmarksdrift og ressursutnyttelse i Norge i eldre tid. In: Gissel S, Österberg E, Göransson S (eds) Plov og pen. Festskrift til Svend Gissel 4. Januar 1991. Det kongelige Bibliotek, København, pp 213-222

Segerström U (1997) Long-term dynamics of vegetation and disturbance of a southern boreal spruce swamp forest. J Veg Sci $8: 295-306$

Segerström U, Bradshaw R, Hörnberg G, Bohlin E (1994) Disturbance history of a swamp forest refuge in northern Sweden. Biol Conserv 68:189-196

Segerström U, Hörnberg G, Bradshaw R (1996) The 9000-year history of vegetation development and disturbance patterns of a swampforest in Dalarna, northern Sweden. Holocene 6:37-48

Skene KR, Sprent JI, Raven JA, Herdman L (2000) Myrica gale L. J Ecol 88:1079-1094

Stene K (2015) Resource exploitation and settlement in mountain areas in southern Norway during the Early Iron Age-an altered perception of landscape and land use. In: Indrelid S, Hjelle KL, Stene $\mathrm{K}$ (eds) Exploitation of outfield resources: joint research at the University Museums of Norway. University of Bergen, Bergen, pp 191-202

Strese E, Tollin C, Hagenblad J (2012) Humulus lupulus in Sweden. Sven Bot Tidskr 106:165-176

Sugita S (1994) Pollen Representation of Vegetation in Quaternary Sediments: Theory and Method in Patchy Vegetation. J Ecol 82:881-897. https://doi.org/10.2307/2261452

Sugita S (2007) Theory of quantitative reconstruction of vegetation I: pollen from large sites REVEALS regional vegetation composition. Holocene 17:229-241. https://doi.org/10.1177/0959683607 075837

Sundquist M, Johansson A (2014) Kartläggning av biologiskt kulturarv i fäbodmiljöer: Värmlands län 2012, vol 4. Länsstyrelsen i Värmlands län, Karlstad

Sveinbjarnardóttir G (1991) Shielings in Iceland: An archaeological and historical survey. Acta Archaeologica 61:73-96

Svensson E (1998) Människor i utmark. Lund Studies in Medieval Archaeology 21. Almqvist \& Wiksell International, Stockholm

Thomas PA, El-Barghathi M, Polwart A (2007) Biological Flora of the British Isles: Juniperus communis L. J Ecol 95:1,404-1,440. https://doi.org/10.1111/j.1365-2745.2007.01308.x

Van Geel B, Zazula GD, Schweger CE (2007) Spores of coprophilous fungi from under the Dawson tephra $\left(25,300{ }^{14} \mathrm{C}\right.$ years BP $)$, Yukon Territory, northwestern Canada. Palaeogeogr, Palaeoclimatol, Palaeoecol 252:481-485

Länsstyrelsen Värmland (2020) Kårebolssätern. https://www.lansstyrel sen.se/varmland/besoksmal/kulturmiljoer-i-varmland/karebolssa tern.html. Accessed 9 July 2020

Vorren K (1986) The impact of early agriculture on the vegetation of Northern Norway. A discussion of anthropogenic indicators in biostratigraphical data. In: Behre K-E (ed) Anthropogenic indicators in pollen diagrams. Balkema, Rotterdam, pp 1-18

Welinder S, Pedersen EA, Widgren M, Myrdal J (1998) Det svenska jordbrukets historia. Jordbrukets första femtusen år: [4000 f. Kr.-1000 e. Kr.]. Natur och kultur/LT i samarbete med Nordiska museet och Stift. Lagersberg, Stockholm

Young GH, McCarroll D, Loader NJ, Gagen MH, Kirchhefer AJ, Demmler JC (2012) Changes in atmospheric circulation and the Arctic Oscillation preserved within a millennial length reconstruction of summer cloud cover from northern Fennoscandia. Clim Dyn 39:495-507 
Zachrisson T, Krzewińska M (2019) The" lynx ladies": Burials furnished with lynx skins from the Migration and Merovingian Periods found in Present-day Sweden. In: Augstein M, Hardt M (eds) Sächsische Leute und Länder: Benennung und Lokalisierung von Gruppenidentitäten im ersten Jahrtausend. Uwe Krebs, Wendeburg, pp 103-119
Publisher's Note Springer Nature remains neutral with regard to jurisdictional claims in published maps and institutional affiliations. 